\title{
How Mothers Use Banyumas Dialect to Their Children and Their Friends in Purwokerto
}

\author{
Rina Heriyanti ${ }^{1,2 *}$ Amir Ma'ruf $^{3,}$ Sulistyowati $^{4}$
}

\author{
${ }^{1}$ Doctoral Student of Universitas Gadjah Mada \\ ${ }^{2}$ UIN Saifuddin Zuhri Purwokerto \\ ${ }^{3,4}$ Universitas Gadjah Mada \\ *Corresponding author.Email: rina.abdurrahman11@gmail.com
}

\begin{abstract}
This research was aimed at exploring the Banyumas dialect usage among parents especially mothers. The language of old generation reflects nowadays situation which indicates that there is a social change through language. The experience of cultural globalization appears in parents' conversation. The participants in this research are natives who live in Purwokerto downtown areas and are able to speak Banyumas language. They are native Banyumas dialect speakers who come from lower middle society as the majority of Purwokerto citizens. The methods are observation, recording and transcript analysis. Result can be described as follows; some of those mothers made the dialect as the first language for their children but some others use bahasa Indonesia meanwhile they still use the dialect to their social circles.
\end{abstract}

Keywords: bilingualism, native speaker, repertoire, language inheritance, Banyumas dialect.

\section{INTRODUCTION}

In the past, first language was identical with the local language since many people were monolingual; they spoke using only their native language as a local cultural product. As Hamers (1993)[3] stated that culture comprises a set of symbolic systems including knowledge, norms, values, belief, language, art, and customs, as well as habits and skills learned by individuals as members of a given society. First language which is identical with the local language is widely known as culture product and has a social relationship with the group through its characteristics.Wittgenstein in Duranti (1997)[2] stated that 'language is a form of life', then to have a language not only means to have instruments to represent events in particular ways. It also means to have the ability to interact with such events, affect them or to be affected by them. The situation in cities and towns becomes different nowadays. Knox (2000)[4] noted that culture changes as the result of consumerism rise and the propagation of materialistic values. People face a shift on the economic behavior and it influences people behaviors. This situation is mainly happen in cities where economic and technological changes have stimulated some cultural changes. It has a great impact on the social behavior and organization of the community. One of the culture changes which are influenced is language.

This is a recording transcript from a 50 years oldlocal woman who accustomed to use Banyumas dialect as her local language and first language:

Nyong dadi kemekel dhèwèk. Yakin nyong geget pisan. Nyong nontonè juga tek ulang-ulang tapi ya èsih tetep ngguyu nonton videonè. Wis bolak-balik tek setèl. Nyong ngguyu kekel yakin nonton kuwè bocah. Mbayangna èngganè ana wong kaya kuwè temenan kaya ngapa ya.

The speaker expressed her feeling in six sentences using Banyumas dialect. She masters the dialect very well since she was born and grew up in Purwokerto. She speaks Banyumas fluently and uses nyong, kemekel, dhèwèk, geget pisan, kekel, mbayangna, èngganè, kaya kuwè, temenan, and ngapa. Nyong is a pronoun which refers to the first person singular; kemekel, kekel, and 
geget, temenan are adjectives which means 'amused'; mbayangna is a Banyumas verb for 'imagine'; dhèwèk, pisan is an adverb which means 'myself' and 'very' ; èngganè, kaya are conjunctions which refer to 'if' and 'as'; kuwè and ngapa as pronouns that refers to the object in the video.

The ability on mastering local language or local dialect for old generation of a community does not seem a big problem. It is showed from the transcript above in which some strong expressions or features of Banyumas dialect are there, such as the iconic words; nyong, ngapa, dhewek, kuwe, pisan and temenan. They are able to speak up in the language since their parents used to do so. Moreover the environment provided a relatively safe condition for the language to survive. At that time many people spoke the language too.

Nowadays almost all people in the world are bilingual or even multilingual. They mingle every time and meet different people with different languages. Languages are used for different occasion and the role of local language is getting limited. It also happens in Purwokerto as the third biggest town in Central Java. The people are accustomed to speak up in Banyumas dialect and also the national language, bahasa Indonesia. It seems that there are some limitations of using the dialect in public areas since bahasa Indonesia is raising its popularity. Sneddon (2003)[5] presented an evident that the percentage of people who could speak bahasa Indonesia had been growing. In 1971 there was $41 \%$ of the total 118 million people could speak the national language. The percentage increased steadily in 1980 with total 90 million of 146 million total populations, which meant the rise was $62 \%$ and the last survey was in 1990 with approximately $83 \%$ of the total population who were able to speak bahasa Indonesia. From the steady rise, it could be inferred that nowadays in 2020 bahasa Indonesia is mastered by almost all citizens of this country. Meanwhile the popularity of Banyumas dialect is on the opposite side since Banyumas dialect speakers are getting lesser in public places.

What are the causes of the decreasing popularity of Banyumas dialect might become the biggest question. Bleakly [2008:296] stated that parental education seems to be an important mediator of the effect of parental English-language skills on child educational outcomes. Children whose parents have lower English proficiency have significantly worse English-language skills for at least the first 11 years of their lives. The role of parents in the study of their children are teaching the child English-language skills, helping them with school assignments and maneuvering the child into the right class and school. Parents play an important role on children first language acquisition since they are the people who responsible on children rising. The language then will be mastered by the children and they bring the language outside their house.

In the past, for common people in Purwokerto the first language that was applied at home was the local language that is Banyumas dialect. It has been widely understood that mother tongue is the name for the first language used by people in a certain community. Mother tongue as a local product has a root with the community and has a social relationship with the group through its characteristics. The language characteristics reflect the people's identity as member of a certain culture. Purwokerto as the capital town of Banyumas is occupied mainly by the people who are able to speak the dialect. Their first language which is identical with the mother tongue is widely known as the culture product of Banyumas.

Nowadays, the community tends to speak many languages. The parents have construct their new language ideology and the parents' language chosen might influence to the surrounding neighborhood. Besides as human beings related to adaptation process, as stated by Thomas (2007)[6] there is a tendency from every people to show that they are not different with the others through language style. People in their area show a tendency to speak up in bahasa Indonesia and this situation influences parents to adapt the new paradigm.

\section{METHOD}

The instruments used for data collection were through a recording and observation. This research examined the language of parents in Purwokerto area. This area represents one of towns which have the highest percentage of Banyumas dialect speakers. The research data is taken randomly by recording informal conversation of some citizens of Purwokerto area. The respondents are women who already become parents and they come from lower middle class society as the majority population there. During the interviews, the respondents made conversation with some people and recorded to get the speech or story that affected them, their friends, their family, or others.

\section{RESULT AND DISCUSSION}

There are some factors that influence the decision of using certain language as the first language; the parent's origin, their education, the popularity of the language etc. Each family is freely to decide which language they are going to use. This is the point that the role of parents becomes very important on deciding 
children's language acquisition. The decision toward first language selection of a family actually brings a big impact on the future of local language.

The use of local or other language firstly is influenced by both parents origin. When they originally come from the place they raise the family, there is a big chance to use the local language. Meanwhile if they do not come from the place they live in now, there might be a little possibility for them to use the local language. The education of the parents also influences the decision on using certain language. The higher the education the more they know about the development and the preference of its society. The popularity of the language is also affected on the decision of language chosen. Parents tend to choose the popular one, the language that might be important for their children's education.

The decision more or less influences the use of the local language in their neighborhood. When the family chooses to use more bahasa Indonesia, the family might be accustomed to use bahasa Indonesia when they talk to their neighbors. This is potentially influenced the surrounding in suburb area since there is a big possibility for the citizens to use non local language. Most people in towns are exposed with more languages and they might come from different places. Meanwhile local language is the product of the native society and it needs speakers to preserve the language. When there is no family applies the language at home and they do not inherit it to their children there will be no speakers anymore. Logically the language disappears not because there are no people. There are many people in that place there but they do not speak using the local language since the language is not popular among them.

The use of Banyumas dialect as the local language of parents is divided into two classifications; The way mothers talk to their children and the way mothers talk to their old friends.

\subsection{Language to Children}

Besides as human beings related to adaptation process, as stated by [6] there is a tendency from every people to show that they are not different with the others through language style. A kind of adaptation of parents nowadays is showed from the language to their children:

a. In the first situation, a woman showed her surprised to the daughter because she went out to the hospital in a hurry and forgot to wear veil.

'Lo dhèk dènèng ibu ora nganggo kudhung." Anakè nyong kaya kiyè "Nggak papa Bu Allah itu Maha Tahu."
"Oh, I forgot to wear my veil!" My daughter answered,'It's ok mam, Allah Knows".

The speaker spoke in Banyumas dialect which proves that some parents using the dialect at home. She was expressing her surprised when she realized that she forgot to wear her veil. 'Lo dhèk dènèng ibu ora nganggo kudhung.' She talked to her daughter using the dialect. However the reply of her daughter is in bahasa Indonesia. 'Nggak papa Bu Alloh itu Maha Tahu.' This is a proof that they are bilingual in their house. They usually use two languages for internal communication.

b. Another woman told a story when she asked her son the reason why he is attracted to a girl named Mutia.

Aku takon kaya kiye "Kak kamu kenapa si suka sama Mutia?" Koh ngguyu ngakak. "Wong dia kan kayanè itu pendiam"

I asked my son, "Why do you fall in love with Mutia?" Laughing he answered, "She is such a calm girl".

A woman asked her son after she knew that he loves a girl named Mutia. She asked him "Kak kamu kenapa si suka sama Mutia?" She directly made the question in bahasa Indonesia. Her son replied, "Wong dia kan kayanè itu pendiam". He said in a mix language. kayanè is Banyumas dialect meanwhile his sentence is in bahasa Indonesia. Bahasa Indonesia for kayanè is 'sepertinya'. A question that the woman asked to her son is in bahasa Indonesia and it proved that although she speak Banyumas fluently she also uses bahasa Indonesia to her children daily.

From the two data there is a tendency to use two languages as the vernacular. Bahasa Indonesia already enters the house and it is introduced by parents, especially mothers.

\subsection{Language to old friends}

Banyumas dialect as a representation of culture plays an important role in local people's life. In the past, the dialect became the mother tongue of families. It is used as the first language which families used for communication among them. They also made the dialect as the first language for their children. Here are some evident that children in the past are accustomed to use Banyumas dialect.

a. A dialogue of two women who are around fifty years old now. They were talking about their children.

Bu Rosi: Korona, dhèwèk priwè kiyè? 
Korona, what should we do?

Bu Lili: Langka sing seneng, bocah ora olih sangu, bakulan langka sing tuku, ojol ora payu. Nèk sing lara Bumen kono lor, rewangè nyong wong kono.

Nobody happy with it, children do not get their pocket money, no seller, nobody use online ojek. If the patient comes from Bumen in the north side, my maid also comes from that place.

Bu Rosi: Sing Kober?

The one from Kober?

Bu Lili: Wis ketemu koh wongè. Nèk bener ya akèh banget ndèyan sing kena ya. Nèk ndeleng gambaran cara nularè ko dadi wedi ya.Kon pada ora panik piwè ya.

It is already detected. If it is right there might be so many victims. When we see the way it spreads out I become afraid, It makes people panic.

Bu Rosi:Kadhang bocah urung paham banget. Ora paham dadi domongi madan angèl.

Sometimes children do not really understand. This condition makes them difficult to listen to us.

Bu Lili: Jajal takon gurunè. Ana baè sing tetep arep mulang.

Ask the teacher. There are also teachers who want to keep teaching.

They were talking about the pandemic that has made them aware and faced some problems on taking care of their children. Both of them speak in Banyumas dialect. There are some new lexical such as corona, ojol (online taxibike) in their utterances. The dialogue shows that they master Banyumas dialect well and they still speak with the dialect nowadays. Banyumas dialect words from their speech are dhewek, priwe, kiye, langka, nyong, koh, ndeyan, domongi, madan, and bae.

From those data above, it seems that parents using Banyumas dialect arbitrarily nowadays. As mothers some of them still speak up using Banyumas dialect and some others not. Meanwhile they are real native Banyumas speakers and it is proved from their talk to friends and neighbors.

The life in urban area reflects on the daily activities of the people which are dynamic and active. The rapidly changing situation brings some effects to the local people and the local culture. Those who have relatively low mobile activities are also experiencing a process. Language as one of the culture community product gets the impact of the social composition change. New people come bring a new way of life and attitude, especially language attitude. It has been widely known that sociolinguistics discusses the problem of society, migrating from one place to another which impact on language use. People adapt with the new situation to adjust their own culture with the new place. This process also happens to local people, they adapt the new neighborhood and the new impact that is brought by those people. They do not really keep speaking up using the language to their children. The transcript shows the real language of adults of Banyumas speaker nowadays. It is a portrait of language dynamic that happens to local language as the product of culture.

From the two conversations above there is a proof of parents not to use their dialect only when they make conversation at home. There is a tendency of using bahasa Indonesia on the communication between parents to their children.

\section{CONCLUSION}

Each language has its own status; such as English is the international language, Germany in some parts of Europe still becomes the lingua franca. Bahasa Indonesia is the national language in thirty four provinces in Indonesia. Banyumas dialect as a representation of culture plays an important role in culture dimension. In the past, the dialect became the mother tongue of families. It is used as the first language which families used for communicating among them. From their speech, all participants are native Banyumas speakers. Some of those mothers made the dialect as the first language for their children but some others mix it with bahasa Indonesia. Language as one of the culture community product gets the impact of the social composition change. New people come bring a new way of life and attitude, especially language attitude. People admit that the national language getting its popularity nowadays. They become bilingual when bahasa Indonesia comes into their homes in a condition where local language becomes the language at home.

The preservation of Banyumas culture especially Banyumas dialect is depend on its speakers. The local language probably has already lost its domestic domain. Meanwhile the more the domain for using the language the more speakers will be. The inheritance process really needs some attention in order to preserve the language.

\section{REFERENCES}

[1] Bleakley, Hoyt \& Aimee Chin. What Holds Back the Second Generation? The Intergenerational Transmission of Language Human Capital among 
Immigrants. The Journal of Human Resources, vol.43. No.2 (Spring 2008), pp. 267-298. 2008.

[2] Duranti, Alessandro. Linguistic Anthropology. Cambridge University Press. USA. 1997.

[3] Hamers, Josieane F \& Michel H.A. Blanc. Bilinguality and Bilingualism. Cambridge University Press. USA.1993.
[4] Knox, Paul \& Steven Pinch. Urban Social Geography an Introduction. Pearson Education Limited. England. 2000.

[5] Sneddon, James. The Indonesian Language. University of New South Wales Press Ltd. Australia. 2003.

[6] Thomas, Linda \& Shan Wareing. Bahasa, Masyarakat, dan Kekuasaan terj. Language,Society and Power. Pustaka Pelajar. Yogyakarta. 2007. 